\title{
GAMBARAN STRES AKADEMIK SAAT PEMBELAJARAN JARAK JAUH (PJJ) PADA SISWA DI SMK NEGERI 1 GODEAN TAHUN PELAJARAN 2020/2021
}

\author{
Tati Indriani \\ Pascasarjana Bimbingan dan Konseling Islam, UIN Sunan Kalijaga Yogyakarta \\ E-mail: tatiindriani@gmail.com .
}

\begin{abstract}
Academic stress is one of the problems experienced by students due to academic pressure to get a score that is in accordance with the Minimum Completeness Standard (SKM), coupled with current conditions that make students have to do distance learning. This study aims to determine the level of academic stress of students at SMK Negeri 1 Godean. This research uses descriptive quantitative method. The population of this research is all students of SMK Negeri 1 Godean. The random sampling technique was used in this research, so that the sample size was 352 students. The results showed that the academic stress of students of SMK Negeri 1 Godean was more in the high category as many as 182 students or 51.7\%. Based on the four aspects of academic stress, there are psychological, physiological, and cognitive aspects that show high categories, while behavior aspects are in the low category.
\end{abstract}

Keywords: Academic stress; Distance Learning; Students

\begin{abstract}
Abstrak: Stres akademik merupakan salah satu permasalahan yang dialami siswa karena tekanan akademik untuk memperoleh nilai yang sesuai Standar Ketuntasan Minimum (SKM), ditambah dengan keadaan saat ini yang membuat siswa harus melakukan pembelajaran jarak jauh. Penelitian ini bertujuan untuk mengatahui tingkat stress akademik siswa di SMK Negeri 1 Godean. Penelitian ini menggunakan metode kuantitatif deskriptif. Populasi penelitian ini yaitu seluruh siswa SMK Negeri 1 Godean. Teknik random sampling digunakan dalam penelitiannya ini, sehingga jumlah sampel sebanyak 352 siswa. Hasil penelitian menunjukkan bahwa stress akademik siswa SMK Negeri 1 Godean lebih banyak pada ketegori kategori tinggi sebanyak 182 siswa atau 51.7\%. Berdasarkan empat aspek stress akademik terdapat aspek psikologis, fisiologis, dan kognitif yang menunjukkan kategori tinggi, sedangkan aspek behavior pada kategori rendah.
\end{abstract}

Kata kunci: Stres Akademik; Pembelajaran Jarak Jauh (PJJ); Siswa

\section{PENDAHULUAN}

Covid-19 sudah menyebar hampir ke seluruh Negara di dunia yang berdampak pada sektor ekonomi, industry, pariwisata, kesehatan, hingga pendidikan. Menurut UNESCO Covid19 ini mempengaruhi lebih dari $91 \%$ dari populasi siswa di dunia karena penutupan sekolah per April 2020 (Primasiwi, 2020). Di Indonesia, pada sektor pendidikan sejak Maret 2020 hingga kini memasuki tahun ajaran 2020/2021. Belajar dari rumah melalui pembelajaran jarak jauh ini sudah disahkan melaui surat edaran Mendikbud No. 4 Tahun 2020. Hal tersebut dilakukan sebagai bentuk upaya agar siswa tetap memperoleh pengalaman belajar dan sekaligus sebagai pencegahan agar tidak menyebar atau dikhawatirkan dapat membuat cluster baru Covid-19.

Belajar dari rumah, artinya siswa dan guru tidak dapat melakukan pembelajaran tatap muka. Hal tersebut menjadi tantangan bagi guru 
untuk tetap dapat memberikan materi pelajaran kepada siswa, serta tantangan bagi siswa untuk tetap belajar di rumah. Pembelajaran yang Pelaksanaan pembelajaran jarak jauh yang sudah berjalan selama 8 bulan ini dilakukan bukan tanpa hambatan baik yang dirasakan guru, siswa, maupun orangtua. Berbagai hambatan, seperti siswa yang tidak memiliki kuota internet, alat pendukung (handphone atau laptop), dan tugas yang dirasa lebih banyak dibandingkan saat pembelajaran di sekolah. Hal tersebut juga membuat guru mendapat kendala saat memberikan materi kepada siswa.Permasalaham tersebut juga terjadi di SMK Negeri 1 Godean yang tidak jarang terdapat siswa yang terlambat untuk mengumpulkan tugas atau bahkan tidak mengerjakan tugasnya. Berdasarkan hasil wawancara dengan salah satu siswa bahwa lebih menyukai belajar di sekolah dibandingkan di rumah atau dilakukan secara daring karena tugas yang diberikan banyak dan kurang memahami materi yang diberikan guru.

Pembelajaran jarak jauh ini menyebabkan hasil belajar atau prestasi belajar siswa menurun. Hal ini diperoleh berdasarkan hasil wawancara dengan beberapa guru mata pelajaran di SMK Negeri 1 Godean bahwa adanya pembelajaran jarak jauh ini membuat nilai yang diperoleh kurang baik, dan masih ada beberapa siswa yang terlambat atau bahkan tidak mengumpulkan tugas. Penjelasan materi setiap mata pelajaran disampaikan melalui media online, serta tugas yang ada disetiap mata pelajaran membuat timbulnya kekhawatiran dan kesulitan siswa dalam menerima materi pelajaran. Kekhawatiran tersebut menimbulkan stress akademik.

Stres akademik umum dialami oleh siswa karena merasa kurang mampu menghadapi tekanan dan tuntuan dalam lingkungan akademiknya untuk memperoleh nilai sesuai standar Skor Ketuntasan Minimum (SKM) yang sudah ditetapkan disetiap mata pelajaran di sekolah masing-masing. Stres akademik didefinisikan sebagai kondisi yang dialami individu sebagai akibat dari tekanan atau tuntutan dari kondisi akademik yang berupa reaksi fisik, perilaku pikiran, dan emosi negatif yang muncul (Barseli, Ifdil, \& Nikmarijal, 2017).

Tekanan tersebut tentu saja akan mengambat siswa dalam menerima materi pelajaran, dan bahkan kesulitan dalam menyelesaikan tugas. Stres akademik ini dapat berpengaruh pada hasil prestasi akademik siswa. Hal tersebut sejalan dengan penelitian yang dilakukan oleh Sudarsana (2019) bahwa stres akademik berpengaruh terhadap prestasi belajar siswa. Faktor yang menyebabkan indiividu mengalami stres akademik yaitu (a) faktor internal, berupa self efficacy, hardiness, dan motivasi; (b) faktor eksternal berupa dukungan sosial (Oktavia, Fitroh, Wulandari, \& Feliana, 2019). Faktor-faktor tersebut mempengaruhi stres akademik yang dialami oleh siswa.

Stres akademik secara berkelanjutan dapat menjadi masalah yang mempengaruhi kesehatan mental dan kesejahteraan siswa (Reddy, Kharismarajanmenon, \& Anjanathattil, 
2018). Hal tersebut karena stress akademik dapat menimbulkan reaksi, seperti yang dikemukakan oleh Cox reaksi stres berupa reaksi psikologi, reaksi fisiologis, reaksi kognitif dan reaksi perilaku (Gibson, Ivancevich, \& Donnelly, 1996). Reaksi stres tersebut akan menghambat siswa dalam menerima materi pembelajaran. Stres yang berkelanjutan dapat membuat siswa menjadi depresi, bahkan mengakibatkan bunuh diri. Hal ini terjadi pada pelajar kelas 2 SMA di Kabupaten Gowa, Sulawesi Selatan diduga bunuh diri karena depresi dengan beban tugas daring dari sekolahnya (Aco, 2020). Berdasarkan hal tersebut, diduga siswa merasa terbebani dengan adanya pembelajaran jarak jauh karena kurang memahami materi pembelajaran yang diberikan, sehingga mengakibatkan siswa kesulitan mengerjakan tugas dan ditambah kuantitas tugas yang bertambah. Berdasarkan masalah tersebut, maka peneliti tertarik untuk menganalisis tingkat stress akademik saat pembelajaran jarak jauh pada siswa di SMK Negeri 1 Godean.

\section{METODE}

Metode penelitian ini menggunakan kuantitatif deskriptif, yaitu bertujuan untuk menjelaskan suatu peristiwa, fenomena, gejala dan kejadian dengan menggunakan angka dalam mengambarkan karakteristik subjek yang diteliti. Subjek dalam penelitian ini siswa. Berdasarkan metodenya penelitian ini menggunakan penelitian survey yang bertujuan untuk mengetahui data tingkat stress akademik siswa. SMK Negeri 1 Godean dengan jumlah 1040 dari kelas X, XI, dan XII. Teknik pengambilan sampel penelitian ini menggunakan random sampling, artinya semua subjek mendapat kesempatan yang sama dan dipilih secara acak. Sampel yang digunakan sebanyak 352 siswa Teknik pengumpulan data menggunakan angket skala Likert untuk mengetahui tingkat stress akademik yang dialami oleh siswa.

\section{HASIL}

SMK Negeri 1 Godean merupakan salah satu sekolah menengah kejuruan yang ada di Kabupaten Sleman, Daerah Istimewa Yogyakarta. SMK Negeri 1 Godean terdiri dari 4 jurusan dengan terdiri dari 10 kelas dalam satu angkatan, yaitu tigas kelas untuk jurusan Akuntansi Keuangan Lembaga (AKL), tigas kelas untuk Otomatisasi Tata Kelola Perkantoran (OTKP), dua kelas Bisnis Daring Pemasaran (BDP), dan dua kelas Multimedia (MM). Responden dalam penelitian ini terdiri dari 352 siswa yang dipilih secara acak. Berikut deskripsi responden dalam penelitian ini berdasarkan kelas dan jenis kelamin.

Tabel. 1 Kakarteristik Responden

\begin{tabular}{lll}
\hline Karakteristik & Frekuensi & $\begin{array}{l}\text { Presentase } \\
(\%)\end{array}$ \\
\hline Kelas & & \\
\hline X & 131 & 37.2 \\
\hline XI & 148 & 42 \\
\hline XII & 73 & 20.7 \\
\hline Jumlah & 352 & 100 \\
\hline Jenis Kelamin & & \\
\hline Perempuan & 328 & 93.2 \\
\hline Laki-laki & 24 & 6.8 \\
\hline Jumlah & 352 & 100 \\
\hline
\end{tabular}


Berdasarkan tabel 1 dapat diketahui bahwa karakteristik responden berdasarkan kelas terdiri dari kelas $\mathrm{X}$ sebanyak 131 siswa atau $37.2 \%$ kelas XI sebanyak 148 atau $42 \%$ dan kelas XII sebanyak 73 atau 20.7\%, sehingga responden penelitian ini didominasi oleh kelas XI. Karakteristik responden berdasarkan jenis kelamin diketahui didominasi oleh perempuan sebanyak 328 atau $93.2 \%$ dan sisanya laki-laki sebanyak 24 atau $6.8 \%$. Hal tersebut dikarenakan siswa SMK Negeri 1 Godean memang didominasi oleh perempuan.

Deskripsi aspek stress akademik terdiri dari aspek psikologis, fisiologis, kognitif, dan perilaku (behavior). Kuesioner stress akademik terdiri dari 16 item pernyataan dari 4 aspek dengan masing-masing aspek terdapat 4 item pernyataan. Sebelumnya dilakukan uji validitas dan reliabilitas dengan bantuan SPSS versi 17. Setelah dilakukan try out kepada 352 diperoleh bahwa 16 item valid dengan indeks validitas 0.127-0.687. Item yang valid, maka diuji reliabilitasnya dengan statistic cronbach's alpha yang diperoleh koefisien reliabilitas sebesar $0.834>0.6$ yang artinya bersifat reliable (Azwar, 2016). Berdasarkan hasil kuesioner, maka dapat diperoleh data sebagai berikut.

Tabel 2. Rerata Skor Stres Akademik Siswa

\begin{tabular}{|c|c|c|c|c|c|c|c|c|}
\hline & $\mathbf{N}$ & Min. & Max. & \multicolumn{2}{|c|}{ Mean } & $\begin{array}{c}\text { Std. } \\
\text { Deviation }\end{array}$ & Striess & akademik. \\
\hline & Statistic & Statistic & Statistic & Statistic & $\begin{array}{c}\text { Std. } \\
\text { Error }\end{array}$ & Statistic & Statistic & Stres akademik terdiri dari \\
\hline $\begin{array}{l}\text { Variabel Stres } \\
\text { Akademik }\end{array}$ & 352 & 18.00 & 64.00 & & & & $\begin{array}{c}47.498 \\
\text { psikol }\end{array}$ & gois fisiologis kognitif dan behavior \\
\hline $\begin{array}{l}\text { Aspek } \\
\text { Psikologis }\end{array}$ & 352 & 5.00 & 16.00 & 11.5085 & .10234 & 1.92004 & 3.687 & mocing terdiri dori item pernyat. \\
\hline $\begin{array}{l}\text { Aspek } \\
\text { Fisiologis }\end{array}$ & 352 & 4.00 & 16.00 & 11.0653 & .12973 & 2.43403 & $\min _{5.924}$ & y-masing terairi dari 4 item pernyataan, \\
\hline Aspek Kognitif & 352 & 4.00 & 16.00 & 10.4830 & .13638 & 2.55866 & 6.æ4аka & nilai maksimal diperoleh $(4 \times 4)=16$ dan \\
\hline $\begin{array}{l}\text { Aspek } \\
\text { Behaviour }\end{array}$ & 352 & 4.00 & 16.00 & 7.96559 & .11242 & 2.10926 & nilai & minimum $(4 \times 1)=4$. Jangkauan $/$ range \\
\hline $\begin{array}{l}\text { Valid } \\
\text { (listwise) }\end{array}$ & 352 & & & & & & dipero & leh $((16-4)+1) \quad=13 \quad$ sedang \\
\hline
\end{tabular}

Pada penelitian ini, subjek penelitian digolongkan berdasarkan kategorisasi tingkat stress akademik yang terdiri dari Sangat Rendah, Rendah, Tinggi, dan Sangat Tinggi. Hal tersebut diperoleh dari skala stress akademik yang setelah dilakukan try out terdiri dari 16 item dari 4 indikator yang masingmasing terdiri dari 4 pernyataan yang valid dengan skor 1-4 sehingga nilai maksimal diperoleh $(16 \times 4)=64$ dan nilai minimum $(16 \times 1)=16$. Jangkauan/range diperoleh $((64-$ 16)+1)= 49 sedangkan banyaknya kelas 4 dan interval sebanyak $(49 / 4)=12$. Berdasarkan hal tersebut, maka diperoleh kategorisasi Stres Akademik dan hasil dalam penelitian ini, yaitu.

Tabel 3. Hasil Kategorisasi Stres Akademik

\begin{tabular}{llll}
\hline Kategori & $\begin{array}{l}\text { Rentang } \\
\text { Skor }\end{array}$ & Frekuensi & $\begin{array}{l}\text { Presentase } \\
(\boldsymbol{\%})\end{array}$ \\
\hline $\begin{array}{l}\text { Sangat } \\
\text { Rendah }\end{array}$ & $16-27$ & 10 & 2.84 \\
\hline Rendah & $28-39$ & 136 & 38.63 \\
\hline Tinggi & $40-51$ & 182 & 51.7 \\
\hline Sangat Tinggi & $52-64$ & 23 & 6.83 \\
\hline Jumlah & & $\mathbf{3 5 2}$ & $\mathbf{1 0 0}$ \\
\hline
\end{tabular}

Berdasarkan tabel 3 diketahui bahwa

stress akademik pada siswa SMK Negeri 1 Godean yang dominan pada kategori tinggi yaitu sebanyak 182 atau $51.7 \%$ pada kategori rendah diperoleh sebanyak 136 atau $38.63 \%$ dan nilai terendah pada kategori sangat tinggi sebanyak 23 atau $6.83 \%$. Hal ini menunjukkan bahwa separuh lebih dari responden mengalami 
banyaknya kelas 4 dan interval sebanyak (13/4) $=3$. Berdasarkan hal tersebut, maka diperoleh kategorisasi hasil aspek psikologis, fisiologis, kognitif, dan behavior sebagai berikut.

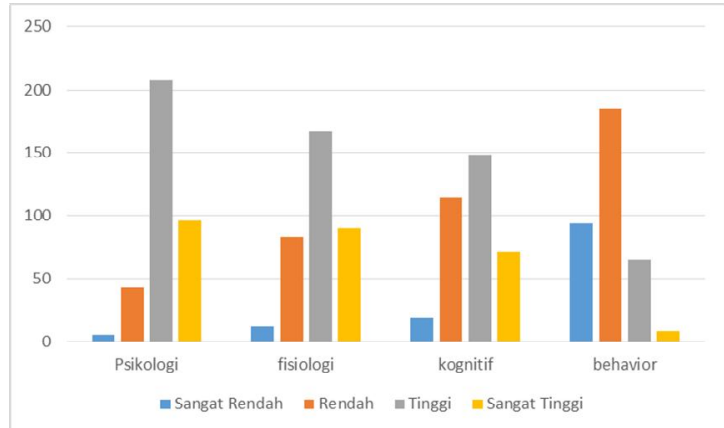

Gambar 1. Grafik Aspek Stres Akademik

Berdasarkan gambar 1 dapat diketahui bahwa stress akademik pada aspek psikologis pada kategori tinggi sebanyak 208 atau 59.09\% dan kategori sangat tinggi sebanyak 96 atau $27.28 \%$. Pada aspek fisiologis tertinggi pada kategori tinggi sebanyak 167 atau $47.44 \%$ dan sangat tinggi sebanyak 90 atau $25.56 \%$. Aspek kognitif nilai tertinggi pada kategori tinggi sebanyak 148 atau $42.04 \%$ dan kategori rendah sebanyak 114 atau 32.38\%. Sedangkan pada aspek behavior tertinggi pada kategori rendah sebanyak 185 atau $52.5 \%$ dan sangat rendah sebanyak 94 atau $26.7 \%$.

\section{PEMBAHASAN}

Hasil analisis tiap aspek variabel stress akademik menunjukkan bahwa sebanyak 51.7\% responden mengalami stress akademik dengan kategori tinggi. Jika dilihat dari indikator/aspeknya hanya 3 aspek yang tergolong dalam kategori tinggi, yaitu psikologis (59.09\%), fisiologis (47.44\%), dan kognitif (42.04\%). Sedangkan aspek behavior termasuk dalam ketegori rendah, yaitu 52.5). Hal tersebut menunjukkan bahwa stress akademik yang dialami siswa SMK Negeri 1 Godean terjadi atau berdampak pada 3 aspek saya, yaitu psikologis, fisiologis dan kognitif, serta tidak memberikan dampak pada aspek behavior.

Stres memberikan dampak positif dan negatif. Stres positif yaitu kondisi apapun yang dapat memberikan motivasi atau dorongan (IKAPI, 2004), sedangkan stress negatif memberikan kondisi yang buruk yang berdampak pada fisiologis, fisik, kognitif, dan perilaku. Stress terjadi karena adanya ketidaksesuaian antara tuntutan yang diterima dengan kemampuan untuk mengatasinya (Looker \& Gregson, 2005). Oleh karena itu, siswa SMK Negeri 1 Godean mengalami stress akademik yang tinggi karena kurang sesuai antara tuntutan saat ini yang membuat siswa harus belajar di rumah menggunakan media online dengan kemampuannya dalam memahami materi pembeajaran.

Siswa pada umumnya terbiasa menerima materi pelajaran di sekolah bersama guru. Sejak adanya Covid-19 pada Maret 2020 sekolah mulai menggunakan system pembelajaran jarak jauh untuk mengurangi penyebaran virus. Kondisi tersebut membuat siswa dan guru tidak dapat melakukan pembeajaran tatap muka. Belajar dengan menggunakan media online tidaklah mudah karena siswa dituntut untuk memperoleh nilai sesuai Standar Ketuntasan Minimal (SKM), serta belajar mandiri di rumah dengan dipandu guru melalui media online. 
Ditambah keterbatasan dalam menunjang pembelajaran seperti smartphone, laptop, kuota, atau masalah jaringan. Hal tersebut yang membuat kemampuan siswa tidak sesuai dengan tuntutan kondisi saat ini, sehingga menghambat pembelajaran dan berdampak pada kondisi siswa.

\section{SIMPULAN}

Berdasarkan hasil analisis data dapat disimpulkan bahwa stres akademik saat pembelajaran jarak jauh pada siswa SMK Negeri 1 Godean 2020/2021 berada pada kategori tinggi. Hal tersebut menandakan sebagian besar siswa mengalami stress akademik yang disebabkan karena adanya ketidaksesuaian antara kemampuan siswa dan tuntutan akademik di sekolah dengan keadaan yang saat ini yang mengharuskan siswa belajar di rumah menggunakan media online, seperti google classroom, whatsapp group. Oleh karena itu, untuk meminimalisir tingkat stress akademik siswa diperlukan adanya dukungan atau kolaborasi dari guru mata pelajaran, wali kelas dan orangtua.

\section{DAFTAR RUJUKAN}

Aco, H. (2020, Oktober). Siswa SMA Bunuh Diri Diduga Stres akibat Tugas Belajar Online. Retrieved from Trubunnews.com: https://www.tribunnews.com/regional/2 020/10/17/siswa-sma-bunuh-dirididuga-stres-akibat-tugas-belajaronline?page $=220$ Oktober 2020.

Azwar, S. (2016). Reliabilitas dan Validitas Edisi 4. Yogyakarta: Pustaka Pelajar.
Barseli, M., Ifdil, \& Nikmarijal. (2017). Konsep Stres Akademik Siswa. Jurnal Konseling dan Pendidikan, 143-148.

Gibson, J., Ivancevich, J. M., \& Donnelly, J. H. (1996). Organisasi: Perilaku, Struktur, Proses. Jilid 1 Edisi 8. Jakarta: Binarupa Aksara.

IKAPI. (2004). Manajemen Stress Cetakan I. Jakarta: Penerbit Buku Kedokteran.

Looker, T., \& Gregson, O. (2005). Managing Stress: Mengatasi Stres secara Mandiri Cetakan I. Yogyakarta: BACA.

Oktavia, W. K., Fitroh, R., Wulandari, H., \& Feliana, F. (2019). Faktor-faktor yang Mempengaruhi Stres Akademik. Prosiding Seminas Nasional Magister Psikologi Universitas Ahmad Dahlan, 142-149.

Primasiwi, A. (2020, Juni 26). Pembelajaran Jarak Jauh perlu Dievaluasi Pemerintah, Pastikan Efektivitasnya. Retrieved from Suaramerdeka 27 Oktober 2020 https://www.suaramerdeka.com/news/n asional/232585-pembelajaran-jarakjauh-perlu-dievaluasi-pemerintahpastikan-efektivitasnya

Reddy, K. J., Kharismarajanmenon, M., \& Anjanathattil. (2018). Academic Stress and its Sources among University Students. Biomedical \& Pharmacology Journal, 11(1), 531-537.

Sudarsana, D. (2019). Pengaruh antara Stres Akademik dengan Prestasi Belajar Siswa Kelas IX SMPN 2 Kemalang . Jurnal Riset Mahasiswa Bimbingan dan Konseling, 204-207. 